OPEN ACCESS

Edited by:

Dipika Mohanty,

Apollo Hospitals Bhubaneswar, India

Reviewed by:

Fabrice Cognasse,

INSERM U1059 SAnté INgéniérie

BIOlogie, France

Hong Yue,

Marshall University, United States

*Correspondence:

Marc Romana

marc.romana@inserm.fr

${ }^{\dagger}$ These authors share first authorship

Specialty section: This article was submitted to

Hematology,

a section of the journal

Frontiers in Medicine

Received: 21 June 2021

Accepted: 30 July 2021

Published: 20 August 2021

Citation:

Nader E, Garnier Y, Connes $P$ and

Romana M (2021) Extracellular

Vesicles in Sickle Cell Disease: Plasma

Concentration, Blood Cell Types

Origin Distribution and Biological

Properties. Front. Med. 8:728693.

doi: 10.3389/fmed.2021.728693

\section{Extracellular Vesicles in Sickle Cell Disease: Plasma Concentration, Blood Cell Types Origin Distribution and Biological Properties}

\author{
Elie Nader ${ }^{1,2 \dagger}$, Yohann Garnier ${ }^{2,3,4 t}$, Philippe Connes ${ }^{1,2}$ and Marc Romana ${ }^{2,3,4 *}$ \\ ${ }^{1}$ Laboratoire Inter-Universitaire de Biologie de la Motricité EA7424, Team "Vascular Biology and Red Blood Cell", Université \\ Claude Bernard Lyon 1, Université de Lyon, Lyon, France, '² Laboratoire d'Excellence du Globule Rouge, PRES Sorbonne, \\ Paris, France, ${ }^{3}$ Université des Antilles, UMR_S1134, BIGR, Pointe-à-Pitre, France, ${ }^{4}$ Université de Paris, UMR_S1134, BIGR, \\ INSERM, Paris, France
}

Prototype of monogenic disorder, sickle cell disease (SCD) is caused by a unique single mutation in the $\beta$-globin gene, leading to the production of the abnormal hemoglobin $S$ $(\mathrm{HbS})$. HbS polymerization in deoxygenated condition induces the sickling of red blood cells (RBCs), which become less deformable and more fragile, and thus prone to lysis. In addition to anemia, SCD patients may exhibit a plethora of clinical manifestations ranging from acute complications such as the frequent and debilitating painful vaso-occlusive crisis to chronic end organ damages. Several interrelated pathophysiological processes have been described, including impaired blood rheology, increased blood cell adhesion, coagulation, inflammation and enhanced oxidative stress among others. During the last two decades, it has been shown that extracellular vesicles (EVs), defined as cell-derived anucleated particles delimited by a lipid bilayer, and comprising small EVs (sEVs) and medium/large EVs (m/IEVs); are not only biomarkers but also subcellular actors in SCD pathophysiology. Plasma concentration of $\mathrm{m} / \mathrm{IEVs}$, originated mainly from RBCs and platelets (PLTs) but also from the other blood cell types, is higher in SCD patients than in healthy controls. The concentration and the density of externalized phosphatidylserine of those released from RBCs may vary according to clinical status (crisis vs. steady state) and treatment (hydroxyurea). Besides their procoagulant properties initially described, RBC-m/IEVs may promote inflammation through their effects on monocytes/macrophages and endothelial cells. Although less intensely studied, sEVs plasma concentration is increased in SCD and these EVs may cause endothelial damages. In addition, sEVs released from activated PLTs trigger PLT-neutrophil aggregation involved in lung vaso-occlusion in sickle mice. Altogether, these data clearly indicate that EVs are both biomarkers and bio-effectors in SCD, which deserve further studies.

Keywords: extracellular vesicles, sickle cell disease, inflammation, coagulation, oxidative stress, endothelial dysfunction 


\section{INTRODUCTION}

Sickle cell disease (SCD) is one of the most frequent autosomal recessive genetic disorder that affects about 3.2 million people worldwide $(1,2)$. SCD is an umbrella term encompassing several sickle cell syndromes having in common the production of an abnormal hemoglobin, named hemoglobin S (HbS) instead of the normal hemoglobin $\mathrm{A}$. HbS is produced as a result of a single base mutation (rs334) in exon 1 of the $\beta$-globin gene, leading to the replacement of a hydrophobic glutamic acid residue by a hydrophilic valine residue at the sixth position of the mature $\beta$-globin chain (3). Sickle cell anemia (SCA) results from the homozygous inheritance of the $\beta^{S}$ mutation, whereas co-inheritance of $\beta^{S}$ with other mutations such as $\beta^{\mathrm{C}}, \beta^{\text {DPunjab }}$, $\beta^{\mathrm{OArab}}$ or $\beta$-thalassemia alleles lead to the other most frequently encountered sickle cell syndromes, namely HbSC, HbSDPunjab, HbSOrab and HbS- $\beta$-thalassemia, respectively, the latter one being subdivided in $\mathrm{HbS} \beta^{0}$-thal and $\mathrm{HbS} \beta^{+}$-thal (4).

Chronic anemia is a common clinical feature associated with the disease, as well as the occurrence of frequent and recurrent vaso-occlusive crises. In addition, SCD patients may exhibit various acute and chronic complications affecting a large number of organs such as the lungs, heart, kidneys, brain, skin and bones (5). Among the four drugs approved for prophylaxis and treatment of complications related to SCD, namely, hydroxyurea (HU), L-glutamine, voxelotor, and crizanlizumab; $\mathrm{HU}$ is the most commonly prescribed treatment (6). It is worthwhile to notice that SCD is characterized by a huge inter-individual variability in its clinical presentation, including for patients sharing the same sickle cell syndromes (7). This clinical variability could be related to the complex pathophysiology of this hemoglobinopathy for which new features and/or actors have recently been identified.

After a presentation of the main interrelated pathophysiological processes of SCD, we will present, in this review, compelling evidence showing that extracellular vesicles (EVs) are not only biomarkers of cellular activation and/or alterations occurring in SCD, but also bio-effectors able to modulate the different pathophysiological mechanisms.

\section{SCD PATHOPHYSIOLOGY: A COMPLEX SCHEMA AND INTERRELATED PATHWAYS}

HbS polymerization is the primary molecular event of SCD pathophysiology. In deoxygenated conditions, HbS proteins aggregate, form fibrous precipitates, and ultimately lead to red blood cell (RBC) sickling. These sickled RBCs are more rigid, fragile and therefore prone to disruption. HbS polymerization induces oxidative damage of the cytoplasmic membrane responsible for the stiffness of these cells and their shortened halflife (8-10). Increased RBC fragility and decreased deformability have been associated to chronic anemia and recurrent painful vaso-occlusive event, respectively (11). However, it has been recognized more than four decades ago that the transit time of RBCs in deoxygenated vascular areas, the territories affected by vaso-occlusive processes, would theoretically be too short to allow the sickling of RBCs (12). Activation and increased adhesiveness of various blood cell types such as neutrophils, monocytes and platelets to the endothelium (13-16), may trigger vaso-occlusion by decreasing blood flow and thereby increasing the RBC transit time in vascular bed with low oxygen content, leading to the sickling of RBCs before they can escape from the microcirculation (16). Sickled RBCs and stress reticulocytes, detected at abnormal level in the blood of SCD patients in response to anemia, also interact with endothelial cells (16). Aggregates of activated platelets and RBCs, monocytes or neutrophils, observed at abnormal levels in SCD patients (1719), may also contribute to decreasing blood flow. The percentage of aggregates has been correlated with disease severity $(20,21)$. Finally, patients with the highest blood viscosity would also be prone to frequent vaso-occlusive crises because of the rise in vascular resistance and the slowing of blood flow (22-24).

\section{Pro-inflammatory State and Oxidative Stress}

SCD has long been recognized as a chronic inflammatory disease associated with enhanced oxidative stress. A key role of intravascular hemolysis in these two conditions has been identified as shown and summarized in Table 1. In SCD patients and more particularly in those with SCA or $\mathrm{S} \beta^{0}$-thalassemia, hemolysis exceeds the capacity of plasma heme-binding proteins such as haptoglobin and hemopexin, leading to their depletion and thus the cell-free circulation of two toxic and oxidative molecules: hemoglobin and heme (29-31). Enhanced autooxidation of $\mathrm{HbS}$ induces the production of reactive oxygen species (ROS) such as superoxide anion, hydrogen peroxide and hydroxyl radical as well as the release of heme from sickle RBCs $(25,26,42)$. Another significant source of ROS is related to the repeated episodes of ischemia-reperfusion occurring during repeated vaso-occlusive events and inducing high plasma levels of xanthine oxidase and NADPH oxidase (27, 28). Although conflicting results on antioxidant levels in SCD patients have been reported (43-45), the antioxidant capacity is insufficient to neutralize the excess of ROS, resulting in chronic oxidative stress (32). Enhanced oxidative stress may lead to endothelial damages through peroxidation of the lipid membrane and/or DNA fragmentation and ultimately cellular apoptosis (33) and has been linked to vascular alterations in SCD patients (34). In addition to these deleterious effects, ROS may promote vascular inflammation and NF- $\kappa B$ endothelial activation through the activation of redox-sensitive transcription factors such as (35). More recently, it has been shown that free heme may activate monocytes/macrophages $(36,37)$, neutrophils (38), platelets (39) and endothelial cells (40) inducing the secretion of pro-inflammatory cytokines and the activation of cell adhesion pathways, key events in heterocellular interactions leading to vaso-occlusion. Several studies have demonstrated that these heme-dependent cellular activations involved the Toll like receptor 4 (TLR4) and the NLRP3 inflammasome signaling pathways in endothelial cells and monocytes/macrophages (40, $46,47)$. In addition, activation of neutrophils, one of the blood cell type playing a key role in vaso-occlusive process (16), by heme also induces the formation of neutrophil extracellular 
TABLE 1 | Involvement of intra-vascular hemolysis in oxidative stress and chronic pro-inflammatory state in SCD.

\begin{tabular}{|c|c|}
\hline References & Main findings \\
\hline$(23,25,26)$ & Enhanced auto-oxidation of HbS leading to the production of ROS and hemolysis \\
\hline$(27,28)$ & Repeated episodes of ischemia-reperfusion inducing high plasma levels of xanthine-oxidase, NADPH and ROS \\
\hline$(29-32)$ & $\begin{array}{l}\text { Exceeding antioxidant capacity of the patient, including low levels of plasma heme and hemoglobin binding proteins such as hemopexin and } \\
\text { haptoglobin leading to enhanced cell-free circulation of heme and hemoglobin }\end{array}$ \\
\hline$(33-35)$ & Vascular inflammation and endothelial activation mediated by ROS through the NF-кB pathway \\
\hline$(36-40)$ & Activation of monocytes/macrophages, neutrophils, platelets and endothelial cells by cell-free heme \\
\hline$(38,41)$ & Production of neutrophil extracellular trap by activated neutrophils leading to higher endothelial expression of VCAM-1 and ICAM-1 \\
\hline
\end{tabular}

traps (NETs) for which high plasma concentration has been detected in SCD patients at steady-state with a further rise during crisis (38). NETs could participate to the chain of deleterious events occurring in SCD by promoting VCAM-1 and ICAM1 endothelial expression (41), two proteins involved in the abnormal interactions between RBCs and endothelial cells (16), and by providing a scaffold for platelets, RBCs and pro-coagulant molecules (48).

\section{Decreased Bioactivity/Bioavailability of Nitric Oxide}

Another deleterious effect of intravascular hemolysis is its impact on the bioactivity/bioavailability of nitric oxide (NO). $\mathrm{NO}$, produced by endothelial NO-synthase, play a key role in the vascular physiology. This free radical induces vasodilation by relaxing perivascular smooth muscles, down-regulates the expression of endothelial adhesion molecules such as ICAM1, VCAM-1, E- and P selectins and inhibits platelets activation $(49,50)$. Cell-free hemoglobin inactivates NO in a dioxygenation reaction leading to the production of methemoglobin and the release of heme into the plasma (51). This inactivation of $\mathrm{NO}$ is very efficient and 1,000 times faster than the one mediated by hemoglobin encapsulated into RBCs (52). Another consequence of hemolysis is the release of arginase by RBCs into the plasma, an enzyme that consumes plasma L-arginine, the precursor of $\mathrm{NO}$, producing ornithine and urea, and thereby exacerbating the decrease of NO bioavailability (53). The decrease of NO bioactivity/bioavailability and thus the resulting endothelial/vascular dysfunction has been linked to a greater risk of developing several SCD complications such as pulmonary hypertension (54), legs ulcers (55), priapism (56), stroke (57) and proteinuria (58).

\section{Pro-coagulation State}

Chronic activation of coagulation is another feature of SCD pathophysiology $(59,60)$. High plasma levels of markers of thrombin production such as prothrombin fragment 1.2 (F1.2), thrombin-antithrombin (TAT) complexes, D-dimers and plasmin-antiplasmin (PAP) complexes have been constantly detected in the plasma of SCD patients (61). Additionally, SCD patients exhibit low levels of protein $C$ and protein $S$, two endogenous anticoagulants, presumably because of their chronic consumption related to ongoing coagulation activation (61). Tissue factor (TF), the primary initiator of extrinsic coagulation pathway, is one of the identified triggers responsible for the coagulation activation. In SCD patients, increased TF expression in monocytes (62), neutrophils (63) and circulating endothelial cells (64) have been detected. In agreement with the reported association between hemolysis marker levels and those of the coagulation activation in SCD patients (62), it has been shown that heme is able to promote TF expression in endothelial cells and blood mononuclear cells $(40,65)$. Moreover, the low levels of contact system proteins also suggest a contribution of the intrinsic pathway to thrombin generation (66). Externalized RBC phosphatidylserine (PS), detected in SCD patients in high amounts, may provide a negative charge surface allowing the docking of tenase and prothrombinase complexes, which in turn may promote the activation of the intrinsic pathway. Significant correlations between PS-positive sickle RBCs and plasma F 1.2, D-dimer and PAP complexes have been reported $(67,68)$. Additionally, high levels of cell-free DNA and nucleosomes released from neutrophils, two other triggers of the contact system activation, have been reported in the plasma of SCD patients (69-71). However, no correlation studies have been performed to our knowledge. If SCD chronic hypercoagulable state has been associated with an increased risk of limited complications such as venous thrombosis $(72,73)$, pulmonary hypertension (74) and in situ thrombosis of small vessels, it is worthwhile to notice that increased thrombin generation may also contribute to vascular inflammation (75).

This brief overview of SCD pathophysiology illustrates the fact that numerous abnormal pathways have been identified so far with multiple inter-relationships between these pathways. During the last decades, the involvement of the so-called extracellular vesicles in this complex pathophysiology has been documented.

\section{EXTRACELLULAR VESICLES IN SCD Classification of Extracellular Vesicles}

Extracellular vesicles (EV) are a generic term for various particles delimited by a lipid bilayer, released from cells and detectable in numerous biological fluids (76). According to their genesis pathways, three main subtypes have been identified and named exosomes, microparticles (MPs) also called microvesicles, and apoptotic bodies. Exosomes, deriving from the endolysosomal pathways or from the outwards budding of the cytoplasmic membrane, are formed within the multivesicular bodies (MVBs) and released upon fusion of MVBs with plasma membrane (77). 


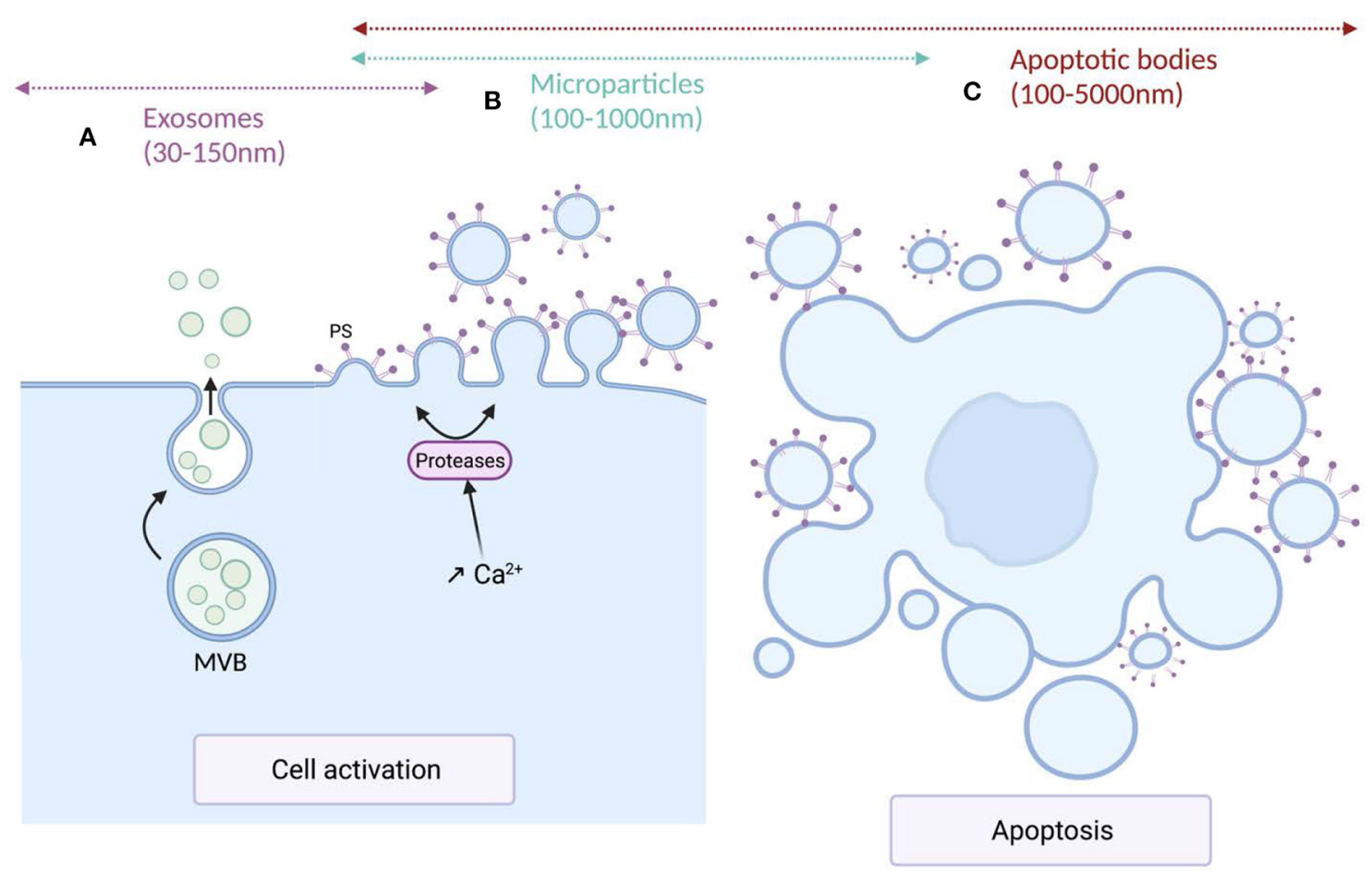

FIGURE 1 | Mechanisms of production and size of the different extracellular vesicles types. (A) Exosomes are formed within multivesicular bodies (MVBs) and released upon fusion of MVBs with plasma membrane. Exosomes (sEVs) exhibit a narrow diameter ranging between 30 and $150 \mathrm{~nm}$. (B) Microparticles (m/IEVs) diameter ranges from 100 to $1,000 \mathrm{~nm}$. MPs derive from the cytoplasmic membrane of activated or apoptotic cells. Cell activation induces an increase of intracellular $\mathrm{Ca}^{2+}$ concentration leading to the translocation of phosphatidylserine (PS) to the outer leaflet of the cytoplasmic membrane and the activation of proteases that cleave the cytoskeleton, weaken its interaction with the cytoplasmic membrane, ultimately leading to the release of $\mathrm{m} / \mathrm{IEV}$. (C) Apoptotic bodies are the largest EV subtypes exhibiting the wider size distribution (100-5,000 nm). They result from cell fragmentation and decomposition of the cell membrane of apoptotic cells.

Compared to the other EV subtypes, exosomes exhibit a narrow size ranging from 30 to $150 \mathrm{~nm}$ in diameter. Microparticles, ranging from 100 to $1,000 \mathrm{~nm}$ in diameter, derive from the cytoplasmic membrane of activated, stressed or apoptotic cells. These conditions induce the increase of intracellular $\mathrm{Ca}^{2+}$ leading to the translocation of phosphatidylserine (PS) to the outer leaflet of the cytoplasmic membrane, a structural characteristic of these EV subtype, and to the activation of proteases that cleave cytoskeleton, weaken its interaction with the cytoplasmic membrane and ultimately allowing the release of MPs (78). Apoptotic bodies, the larger EV subtypes exhibiting the wider size distribution $(100-5,000 \mathrm{~nm})$ result from cell fragmentation and decomposition of the cell membrane of apoptotic cells $(79,80)$. The size distribution and the biogenesis pathways of the different EV subtypes are illustrated in Figure 1.

Over time, several techniques have been implemented for quantitative and/or qualitative analysis of EVs such as flow cytometry, dynamic light scattering, nanoparticles tracking analysis, scanning and transmission electron microscopy, cryoelectron microscopy and atomic force microscopy (81). Up to now, flow cytometry is clearly the most commonly used technique for EV analysis. Using fluorescent probes such as labeled Annexin V, a protein with high affinity for PS, and labeled antibodies directed against membrane proteins specific of each blood cell types, plasma concentration and cellular origin of EVs could be theoretically established. However, flow cytometry encounters several shortcomings including limited sensibility and resolution, leaving uncharacterized a significant proportion of the smallest EVs even with the most sensitive flow cytometers (82). Besides, it has been shown that numerous parameters such as technical characteristics of flow cytometers, pre-analytical and analytical conditions among others, significantly impact on both quantitative and qualitative EVs analysis. Since these pitfalls and limits have been extensively reviewed (83-85), they will not be discussed in the present review. To overcome these limitations, specific recommendations and guidelines have been produced $(86,87)$. However, most of the studies that aimed to characterize EVs in SCD, have been performed previously to their publication or did not apply these recommendations. Conflicting results found in the literature and described later are undoubtedly related to non-standardized procedures.

Originally described as dust cells in the late sixties (88), it has been demonstrated since then that EVs can mediate intercellular communication in both physiological and pathophysiological conditions (89-91) through the transfer to the recipient cells of their biological content, i.e., proteins, lipids, mRNA and miRNA $(90,92)$. In addition, high plasma levels of EVs have been detected in various diseases such as cardiovascular diseases, 
TABLE 2 | Comparison of blood cell type-derived EVs determined by flow cytometry between SCD patients and healthy controls.

\begin{tabular}{|c|c|c|c|c|}
\hline References & Type of EVs & Patients included & EV cellular origin assessed ${ }^{a}$ & Compared to healthy controls \\
\hline Feng et al. (95) & $\mathrm{m} / \mathrm{IEVs}$ & 27 SCD patients & $\begin{array}{l}\text { - RBCs (CD235a), } \\
\text { - Platelets (CD41a), } \\
\text { - Monocyte (CD14), } \\
\text { - Endothelial cells (CD114) }\end{array}$ & $\begin{array}{l}-\lambda_{\text {in SCD }} \\
-\lambda_{\text {in SCD }}\end{array}$ \\
\hline Witwer et al. (96) & $\mathrm{m} / \mathrm{IEVs}$ & 50 SCD patients: & $\begin{array}{l}\text { - RBCs (CD235a), } \\
\text { - Platelets (CD41a), }\end{array}$ & $\begin{array}{l}-\nearrow_{\text {in SCD }} \\
-\boldsymbol{T}_{\text {in SCD }}\end{array}$ \\
\hline Shet et al. (97) & $\mathrm{m} / \mathrm{IEVs}$ & 92 SCD patients: & $\begin{array}{l}\text { - RBCs (CD235a), } \\
\text { - Platelets (CD41a), }\end{array}$ & $\begin{array}{l}-\lambda_{\text {in SCD }} \\
-\lambda_{\text {in SCD }}\end{array}$ \\
\hline Tantawy et al. (98) & $\mathrm{m} / \mathrm{IEVs}$ & 29 SCA patients & $\begin{array}{l}\text { - RBCs (CD235a), } \\
\text { - Platelets (CD41a), }\end{array}$ & $\begin{array}{l}-\nearrow_{\text {in SCA }} \\
-\nearrow_{\text {in SCA }}\end{array}$ \\
\hline $\begin{array}{l}\text { Gerotziafas et al. } \\
\text { (99) }\end{array}$ & $\mathrm{m} / \mathrm{IEVs}$ & 45 SCD patients & $\begin{array}{l}\text { - RBCs (CD235a), } \\
\text { - Platelets (CD61), } \\
\text { - Monocyte (CD14), } \\
\text { - Endothelial cells (CD106) }\end{array}$ & $\begin{array}{l}-\nearrow_{\text {in SCD }} \\
-\nearrow_{\text {in SCD }} \\
-\nearrow_{\text {in SCD }} \\
-\nearrow_{\text {in SCD }}\end{array}$ \\
\hline Kasar et al. (100) & $\mathrm{m} / \mathrm{IEVs}$ & 138 SCD patients & - RBCs (CD235a) & $-\boldsymbol{T}_{\text {in SCD }}$ \\
\hline van Tits et al. (101) & $\mathrm{m} / \mathrm{IEVs}$ & 232 SCA patients & $\begin{array}{l}\text { - RBCs (CD235a), } \\
\text { - Reticulocytes (CD71) } \\
\text { - Platelets (CD61), } \\
\text { - Leucocytes (CD45), } \\
\text { - Endothelial cells (CD106) }\end{array}$ & $\begin{array}{l}-\lambda_{\text {in SCA }} \\
-\lambda_{\text {in SCA }} \\
-\nearrow_{\text {in SCA }} \\
-\lambda_{\text {in SCA }}\end{array}$ \\
\hline $\begin{array}{l}\text { Dembélé et al. } \\
\text { (102) }\end{array}$ & sEVs & 22 SCA patients & $\begin{array}{l}\text { - RBC (CD235a), } \\
\text { - Platelets (CD31/CD42b), } \\
\text { - Monocytes (CD45/CD14), } \\
\text { - Endothelial cells (CD309/CD133) } \\
\text { - Progenitor cells (CD309/CD34) }\end{array}$ & 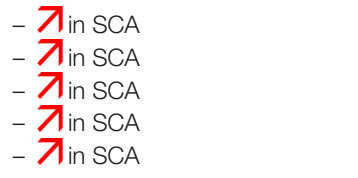 \\
\hline Garnier et al. (103) & sEVs & 33 SCD patients & $\begin{array}{l}\text { - RBCs (CD235a), } \\
\text { - Platelets (CD31/CD42b), } \\
\text { - Monocytes (CD45/CD14), } \\
\text { - Endothelial cells (CD309/CD133) } \\
\text { - Lymphocytes (CD45) } \\
\text { - Progenitor cells (CD309/CD34) }\end{array}$ & $\begin{array}{l}-\nearrow_{\text {in SCA }} \\
-\nearrow_{\text {in SCA }} \\
-\nearrow_{\text {in SCA }} \\
-\nearrow_{\text {in SCA }} \\
-\nearrow_{\text {in SCA }}\end{array}$ \\
\hline
\end{tabular}

aln bracket is indicated the blood cell specific CD used to determine the cellular origin of EVs.

artherosclerosis, cancer and diabetes (93). All these disorders share several key pathophysiological components with SCD such as, increased risk of thrombosis, endothelial dysfunction, enhanced oxidative stress and high level of inflammation which may lead to increased release of EVs. For example, proinflammatory state and ischemic-reperfusion induce cellular activation and/or apoptosis and thus the production of EVs from various blood cell types such as endothelial cells, leukocytes, platelets and red blood cells as observed in ischemic coronary disease (94). In diabetic patients, endothelial dysfunction, evaluated by endothelial-dependent flow-mediated dilation, has been positively correlated with EV concentration released mostly by apoptotic endothelial cells (95). Altogether, these data strongly suggest that pro-inflammatory-state, pro-thrombotic-state and endothelial dysfunction are among the pathophysiological pathways associated with increased release of EVs.

It is important to notice that most of the reported studies in the field of EVs in SCD, do not provide any information on the biogenesis of these vesicles and used either their size and/or their density to classify them. Therefore, in the present review, we will use the terms of small EVs (sEVs) and medium/large EVs (m/lEVs), for exosomes and microparticles/microvesicles, respectively, according to the classification proposed by the
International Society of Extracellular Vesicles (96). Knowing that there are significant overlaps of both size and density parameters between each EV subtype, this classification could be partly artificial and some of the reported associations and/or biological functions could be related to a mixture of different EV subtypes instead of one specific subtype.

\section{Plasma Levels of Extracellular Vesicles in SCD} In Steady State Condition

As indicated in Table 2, several reports have documented higher levels of EVs in SCD patients at steady state, i.e., at distance of acute complication and blood transfusion, compared to healthy individuals $(97-102,104,105)$. Since most of these studies were performed using flow cytometers unable to detect sEVs, the previous observations are undoubtedly related to $\mathrm{m} / \mathrm{lEVS}$. Increased plasma concentrations of $\mathrm{m} / \mathrm{lEVs}$ were detected not only in SCA patients but also in SC patients, although the levels reached in the latter population were not as high as in the former one (103). So far, no study specifically dedicated to patients with $\mathrm{S} \beta$-thalassemia has been conducted. These $\mathrm{m} / \mathrm{lEV}$ s derived mainly from platelets and RBCs while those originated from the other blood cell types such as endothelial cells, monocytes or 
granulocytes, were usually either barely detectable or detectable at low levels. In contrast, rather limited number of studies have been conducted on sEVs in SCD patients. Two reports from the same group described higher plasma concentration of sEVs in children and young adults with SCD at steady state level compared to controls $(106,107)$. The cellular origins of sEVs detected in SCD patients show a wider distribution than those of $\mathrm{m} / \mathrm{lEVs}$, being originated from RBC precursors, endothelial cells, lymphocytes, monocytes and platelets. All these plasma EV subtypes exhibit high concentrations in SCD patients, compared to controls, except for those originated from platelets. To our best knowledge, no study dedicated to apoptotic bodies has been performed in SCD yet.

The clinical severity of the disease has been linked to plasma EV levels measured at steady state. Severe vaso-occlusive phenotype $(98,104)$ and positive history of acute chest syndrome, pulmonary hypertension (98), osteonecrosis of the femoral head (108) and leg ulcers (102) have been associated with high concentration of $\mathrm{m} / \mathrm{lEV}$ s released from various blood cell types. In contrast, lower concentration of reticulocyte-derived and $\mathrm{RBC}$-derived $\mathrm{m} / \mathrm{lEVs}$ were detected in SCA patients with a positive history of priapism and retinopathy, respectively, compared to SCA patients without these complications (102).

Few studies have specifically addressed the relationship between sEVs and the previous clinical course of SCD. Based on a cohort of 22 SCA children followed since birth and classified according to the painful vaso-occlusive rate, higher counts of sEVs originated from endothelial cells, progenitor cells, monocytes and lymphocytes were detected in the most severe patients compared to the milder ones (106). In addition, comparison of sEVs miRNA content between these two groups lead to the identification of miRNA expression patterns specific of the disease severity. A classification based on acute chest syndrome rate failed to detect difference in sEV levels except for those derived from monocytes (107).

Overall, if high levels of EVs have been repeatedly detected in SCD patients at steady-state, few of the associations with the severity of the clinical course of the disease have been reproduced and the usefulness of both EV subtypes as biomarkers of previous occurrence of specific SCD complication needs to be confirmed.

\section{During Acute Complication}

It has been shown that the clinical status of the SCD patients may impact $\mathrm{m} / \mathrm{lEV}$ s concentration. Higher levels of $\mathrm{m} / \mathrm{lEV}$ s have been reproducibly reported during vaso-occlusive crisis compared to steady state condition $(97,98,100,101,109)$. However, the cellular origins of these vesicles, for which an increase had been detected, varied from one study to another. Several parameters may explain these discrepancies such as the study design, clinical definition of sickle cell crisis, the delay between blood sampling and hospital admission, and pre-analytical and analytical procedures used $(110,111)$. In the larger longitudinal survey published so far, in which 32 SCA patients were analyzed both at steady state and during painful vaso-occlusive crisis, a 2 -fold increase in blood concentration of RBC-derived $\mathrm{m} / \mathrm{lEVs}$ has been detected (112), in agreement with previous reports $(98,100,109)$, as well as an increase of PS-externalization by these m/lEVs. Further studies are warranted to confirm and better describe these qualitative changes which impact on the biological properties of these vesicles, as described in subsequent paragraphs. To our knowledge, analysis of sEVs during the occurrence of SCD complications has not been performed yet.

\section{In Patients Treated With Hydroxyurea}

The impact of hydroxyurea (HU) treatment on the concentration of $\mathrm{m} / \mathrm{lEVs}$, the only EV subtype analyzed so far in relation to $\mathrm{HU}$ treatment, is still controversial. Indeed, decreased (98, $113,114)$, increased $(109,115)$ and unchanged $(96,105) \mathrm{m} / \mathrm{lEV}$ concentrations have been reported in HU-treated SCA patients, compared to untreated patients. Knowing the wide distribution of $\mathrm{m} / \mathrm{lEV}$ concentration in SCA patients $(103,112,113)$, these contradictory results could be related to the cross-sectional design of these studies. In order to reduce the inter variability, we have implemented a longitudinal follow-up of SCA patients before and after 2 years of HU treatment (116). While no change in $\mathrm{m} / \mathrm{lEV}$ concentration was detected, two qualitative parameters of $\mathrm{m} / \mathrm{lEVs}$ originated from RBCs were modified during the course of HU treatment: EVs size was increased and their PS exposure was decreased. Such HU-related changes could affect their biological properties and need to be confirmed by further longitudinal studies.

\section{Triggering Pathways of EV Release in SCD}

Several triggers and pathways of EV biogenesis in SCD pathophysiological context have been identified for two blood cell types: RBCs and platelets.

After the initial observation that repeated $\mathrm{RBC}$ sickling/unsickling induce the shedding of EVs (117), it has been shown that oxidative stress resulting from accelerated denaturation of $\mathrm{HbS}$, leads to RBC membrane protein oxidation, weaker interactions between the membrane skeleton and lipid bilayer, destabilization of RBC cytoplasmic membrane and ultimately to EVs shedding (118-120). More recently, the involvement of hyperphosphorylation of Band 3, induced by the inhibition of SCD RBC tyrosine phosphatase (121, 122), in the release of EVs, has been documented. Indeed, direct relationship between tyrosine phosphorylation of Band 3 and the concentration of RBC-derived $\mathrm{m} / \mathrm{lEV}$ s has been detected in SCD patients while in vitro inhibition of Syk kinases, the kinases responsible for Band 3 phosphorylation, was associated with lower shedding of these vesicles (123). Phosphorylation of Band 3 has also been linked to storage lesions of RBCs and $\mathrm{RBC}$ vesiculation (124). In addition, eryptosis, a condition associated with clustering of Band 3, induced by Band 3 phosphorylation, and characterized by increased RBC calcium level, PS externalization, RBC shrinkage, energy depletion and membrane blebbing, has been associated with the release of $\mathrm{m} / \mathrm{lEVs}$ (125). Since Band 3, the most abundant protein of the $\mathrm{RBC}$ cytoplasmic membrane, plays a key role in membrane stability and deformability by linking the lipid bilayer to the cytoskeleton, it is not surprising that plasma level of $\mathrm{m} / \mathrm{lEVs}$ produced by RBCs were reproducibly associated with both anemia level and hemolytic markers levels in SCD patients (103-105, 114, 126, 127). 
Another identified biogenesis pathway of RBC-derived EVs relies on the dysregulation of the metabolism of sphingolipids. Sphingomyelinase, one of the key enzymes of this metabolic pathway, hydrolyzes sphingomyelin, a lipid representing $10 \%$ of the total lipid of the plasma membrane. It is activated by membrane curvature and increased mechanical bending stress in RBCs (128). The increased activity of sphingomyelinase in sickle RBCs from sickle mice compared to control mice, was linked to the generation of both sEVs and $\mathrm{m} / \mathrm{lEVs}$. Moreover, in vivo and in vitro pharmacologic inhibition of sphingomyelinase reduces their release from RBCs (129).

It has also been shown that infusion of thrombospondin1 , a protein stored in platelet $\alpha$-granules and released upon activation, in mouse models, induces the shedding of RBC$\mathrm{m} / \mathrm{lEVs}$ through CD47 signaling pathway, a process exacerbated in sickle mice (130).

As previously described, several hemolysis end-products like cell-free hemoglobin and heme may activate platelets. The binding of $\mathrm{HbS}$ to GP1b $\alpha$ at the platelet membrane level induces a signaling process through Lyn, PI3K, Akt and ERK pathways and the shedding of $\mathrm{m} / \mathrm{lEVs}$ (131). The binding of heme to TLR4, expressed not only by platelets but also by monocytes/macrophages, neutrophils and endothelial cells, activates these cells and presumably induces the release of EVs. Activation of these cells by inflammatory mediators such as cytokines, for which high levels are detected in SCD patients, may also lead to EVs shedding. In addition, in vitro experiments have shown that decreasing $\mathrm{RBC}$ oxidative stress, using the anti-oxidant $\mathrm{N}$-acetylcysteine, was associated with lower shedding of $\mathrm{m} / \mathrm{lEVs}$ by sickle RBCs (125). It is therefore tempting to hypothesize that ROS may also be involved in the release of EVs by these cells. However, no report has yet tested these hypotheses in SCD clinical context to our knowledge.

\section{EXTRACELLULAR VESICLES AS BIO-EFFECTORS OF SCD}

Since EVs exhibit biological properties, they could modulate, negatively or positively, pathophysiological SCD pathways. Some data suggest that vesiculation of cells could be a self-protective mechanism. Indeed, it has been shown that half of RBCderived $\mathrm{m} / \mathrm{lEVs}$ circulating in the plasma of healthy individuals were linked with natural antibodies directed against antigenassociated band 3 protein, a well-known senescence marker of RBCs, while a much lower fraction of RBCs was positive for this senescent marker (132). Based on these observations, it has been hypothesized that vesiculation may be a mechanism of removing damaged proteins from otherwise healthy cells and thereby increasing their lifespan. However, this phenomenon was described only for RBCs and may not be effective for the other blood cell types.

Besides this potential beneficial aspect of vesiculation, the involvement of EVs in several abnormal pathophysiological pathways of SCD has been documented, based on either association studies and/or direct testing of their biological properties in sickle mouse models or using in vitro experiments. These biological properties are summarized in Figure 2.

\section{Impact on Coagulation}

EVs generated in vitro from stimulated monocytes, RBCs and platelets using calcium ionophore are able to trigger thrombin generation through TF-dependent or TF-independent mechanisms, when they are generated from the former and from the two latter cell types, respectively $(133,134)$. Accumulating evidence indicated that both activation pathways of coagulation are supported by EVs in SCD. The initial relationship detected by Setty et al. (68) in SCD patients between RBC-derived m/lEVs and plasma prothrombin fragment F1.2 has since then been confirmed and extended using other markers of coagulation activation $(99,126)$. In addition, RBC-m/lEVs of SCD patients were positively associated with acceleration in the propagation phase of thrombin generation while in vitro thrombin generation induced by these EVs was partly inhibited by anti-human factor XI (99). Activation of intrinsic coagulation pathway driven by $\mathrm{RBC}$ - and platelet-derived $\mathrm{m} / \mathrm{lEVs}$ relies to the exposure of PS at their outer membrane leaflet which provides a suitable surface for the assembly of tenase and prothrombinase complexes (78). While platelet-derived $\mathrm{m} / \mathrm{lEV}$ s are usually described as the most abundant $\mathrm{m} / \mathrm{lEVs}$ detected in SCD patients, most of the studies detected association between RBC-EVs and coagulation activation. It is therefore temping to hypothesize that these unexpected results could be related to the higher density of externalized PS in RBC-m/lEVs than that of PLT-EVs (103) and therefore could activate coagulation more efficiently. In addition, it has been recently shown that $\mathrm{m} / \mathrm{lEV}$ s released during red cell storage, can trigger coagulation activation not only through the canonical intrinsic pathway but also through the activation of a non-canonical pathway in which Kalikrein directly activates factor IX leading to thrombin generation (135). This observation also suggests that $\mathrm{RBC}$-derived $\mathrm{m} / \mathrm{lEV}$ s could be more efficient than platelet-derived $\mathrm{m} / \mathrm{lEVs}$ in coagulation activation, but whether $\mathrm{m} / \mathrm{lEV}$ s produced in the plasma of SCD patients exhibit similar biological properties remains unknown. In contrast to these studies, Shet et al. (97) reported positive relationship between TF-positive m/lEVS originated from monocytes and coagulation markers as well as the partial inhibition of the procoagulant activity of sickle m/lEVs by TF-neutralizing antibody in in vitro assays (97). Despite these discrepancies, these data clearly documented the involvement of $\mathrm{m} / \mathrm{lEVs}$ in the hypercoagulation and prothrombotic states, known to be significant contributors to vaso-occlusion in SCD (16).

\section{Impact on Pro-inflammatory Status}

The capacity of EVs to interact with and to induce an inflammatory phenotype of several vascular cell types has been documented by several studies in the SCD context.

$s E V s$ and $\mathrm{m} / \mathrm{lEVs}$ produced in vitro from sickle RBCs, can be internalized by monocytes/macrophages leading to the secretion of several pro-inflammatory cytokines (129). In addition, peripheral blood mononuclear cells (PBMC) incubated with these EVs exhibited an increased adhesion to endothelial cells. Using $\mathrm{m} / \mathrm{lEVs}$ produced in vitro by sickle RBCs, Camus 


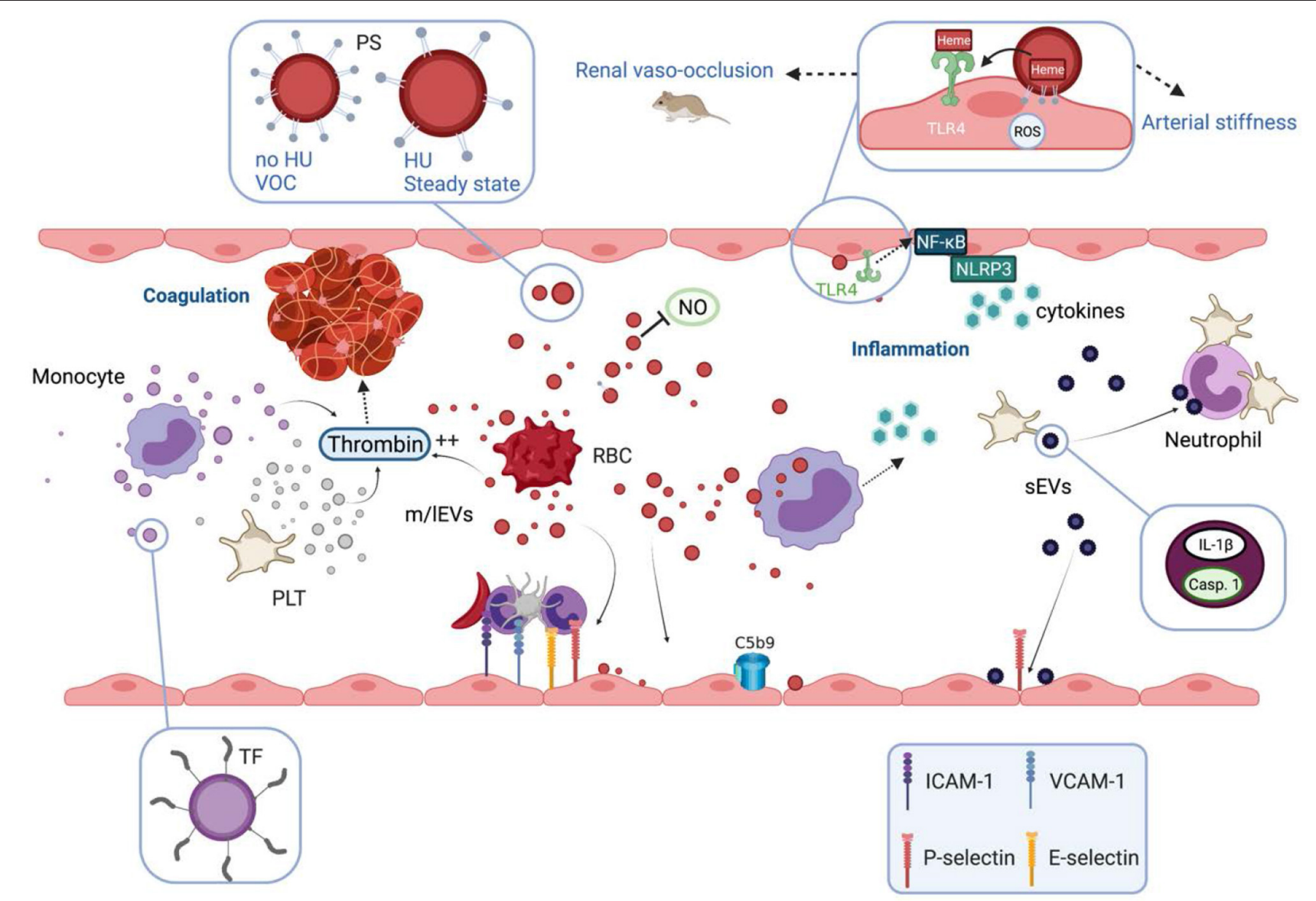

FIGURE 2 | Biological properties and pathophysiological consequences of extracellular vesicles in sickle cell disease. Extracellular vesicles (EVs) partly cause the hypercoagulant and prothrombotic state known in sickle cell disease (SCD). m/IEVs generated in vitro from stimulated monocytes, RBCs or platelets are able to trigger thrombin generation through TF-dependent and TF-independent mechanisms. Intrinsic coagulation pathway activation by RBC- and platelet-derived m/IEVs relies on the exposure of phosphatidylserine at their outer membrane leaflet. EVs also contribute to the inflammatory state of SCD patients. $\mathrm{m} / \mathrm{IEV}$ s produced in vitro from sickle RBCs can be internalized by monocytes leading to the secretion of several proinflammatory cytokines and can increase the adhesion of monocytes to the endothelium. $\mathrm{m} / \mathrm{IEV}$ s generated in vitro by sickle RBCs have been shown to promote renal vaso-occlusion in sickle cell mice and to induce endothelial cell apoptosis and ROS production. The high level of PS exposed at the surface of these vesicles, as well as their content in heme, could play a role in their deleterious effects on the vascular function. RBC-m/IEVs directly isolated from SCD patients' blood samples, promote the expression of adhesion molecules (ICAM-1, E-Selectin) and the production of pro-inflammatory cytokines by cultured endothelial cells. The endothelial activation mediated by these EVs involves the TLR4 signaling pathway. These proinflammatory properties are considerably reduced for m/IEVs obtained from patients treated with HU, which exhibit low PS externalization. In contrast, m/IEVs collected from patients during vaso-occlusive crisis exhibit high PS exposure and have deleterious effects on endothelial cells. RBC-m/IEVs could decrease NO bioavailability through their scavenging effects. In addition, both externalized PS and heme exposed by RBC-derived m/IEVs obtained using a calcium ionophore, have been shown to activate complement system on endothelial cell membranes. In humanized SCD mice, the stimulation of platelets leads to the release of sEVs highly loaded with IL-1 $\beta$ and caspase-1, which bind to neutrophils and promote platelet-neutrophil aggregation. VOC, vaso-occlusive crisis; NO, nitric oxide; ROS, reactive oxygen species; HU, hydroxyurea; PS, phosphatidylserine; TF, tissue factor; TLR4, toll like receptor 4; Casp.1, caspase 1; PLT, platelets; RBC, red blood cells.

et al. (130, 136) showed that their infusion in sickle mice promoted renal vaso-occlusion, reduced vasodilation of ex vivo isolated micro-vessels and induced endothelial cell apoptosis as well as ROS production $(130,136)$. The high level of PS externalized at the surface of these vesicles, as well as the fact that they contain a large amount of heme, would play a role in the impaired vascular function (130, 136). Both externalized PS and heme exposed by RBC-derived $\mathrm{m} / \mathrm{lEVs}$ obtained using calcium ionophore, promoted alternative and terminal complement activation pathway in serum and on endothelial cell membrane (137).
Since content, structural characteristics and biological properties of EVs vary according to triggering factors $(138,139)$, we designed studies aiming at analyzing the biological properties of $\mathrm{m} / \mathrm{lEVs}$ directly isolated from SCD patients in various clinical conditions. In these more pathophysiological relevant conditions, we have shown that $\mathrm{m} / \mathrm{lEVs}$ isolated from patients at steady state induced ICAM-1 expression in cultured endothelial cells and thereby increased the adhesion of neutrophils (140). To decipher which blood cell type-derived $\mathrm{m} / \mathrm{lEV}$ s are responsible for these biological effects, we used immuno-depletion to select vesicles according to their cellular origins and identified those 
released by RBCs as the main contributors (140). While preincubation of $\mathrm{m} / \mathrm{lEV}$ s with annexin- $\mathrm{V}$, a PS blocker, abolished the induced endothelial ICAM-1 overexpression, we have shown that the proinflammatory properties of $\mathrm{m} / \mathrm{lEV}$ s collected during a vaso-occlusive crisis, a condition associated with high PS externalization of $\mathrm{m} / \mathrm{lEVs}$ (114), were exacerbated. In contrast, these proinflammatory properties were considerably reduced for $\mathrm{m} / \mathrm{lEV}$ s obtained from patients treated with $\mathrm{HU}$, which exhibited low PS externalization (116). In addition, we presented evidence that the endothelial activation mediated by these EVs also involved TLR4 signaling pathway (125). In this study, we also detected a direct relationship between arterial stiffness in SCA patients and plasma concentration of RBC-m/lEVs. EVs could also disturb NO bioavailability through their NO scavenging effects (141). Altogether, these data strongly suggest that externalized PS, alone or associated with heme, or hemoglobin retained by these EVs, play a significant role in the induced endothelial cell dysfunction. However, the involved signaling pathways partly remain to be deciphered.

It has also been documented that sEVs, purified from SCD patients, could modify the phenotype of several vascular cell types. Indeed, Khalyfa et al. have shown that sEVs obtained from SCD patients exhibiting severe vaso-occlusive phenotype, decreased endothelial permeability, promoted Pselectin expression in endothelial cells, and induced a proadhesive phenotype of monocytes (106). However, the cellular origin of the vesicles responsible for these biological effects remains unknown. sEVs released from platelets may also play a significant role in the occurrence of acute chest injuries. In SCD humanized mice, a specific activation of platelets by LPS, an agonist of TLR4, leads to the activation of the NLRP3 inflammasome and to the release of sEVs highly loaded with IL- $1 \beta$ and caspase- 1 , which bind to neutrophils and promote platelet-neutrophil aggregation in lung arterioles (142). Such heterotypic aggregates may cause arteriolar microthrombi and mimic chest injuries observed in SCD patients.

\section{FUTURE DIRECTIONS}

A recently described feature of EVs may be significantly relevant in SCD etiology and clearly deserves further studies. Fitzgerald et al. demonstrated that cytokines are not only released in soluble form, but also encapsulated in EVs in numerous biological fluids (143). They also showed that the relative fractions of free and EVassociated forms of cytokines are regulated and modulated upon cellular activation. EV-retained cytokines remained biologically active and could be released to their targeted cells by a yet uncharacterized mechanism. Since cytokines inside the vesicles are not detected by standard target cell-free assays

\section{REFERENCES}

1. Piel FB, Patil AP, Howes RE, Nyangiri OA, Gething PW, Williams $\mathrm{TN}$, et al. Global distribution of the sickle cell gene and geographical confirmation of the malaria hypothesis. Nat Commun. (2010) 1:104. doi: $10.1038 /$ ncomms1104 and multiplexed immunoassays (143), the blood content of these inflammatory mediators has been underestimated in SCD patients so far, and the relationships between SCD clinical complications and cytokine levels are clearly issues which need to be reanalyzed. The quantifications of both free cytokines and those conveyed by EVs in SCD patients in various clinical conditions, could reduce this caveat and provide a better view of the inflammatory processes involved. Besides their cytokine contents, the other bio-active molecules contained in EVs, and specifically those produced in vivo, remain to be better characterized and/or to be identified. Indeed, very few studies have addressed this issue and the content of EVs reported so far has been mostly obtained from vesicles generated in-vitro using artificial experimental conditions. Future studies focusing on the description of in-vivo generated EVs characteristics are still pending. At last, the capacity of these EVs to modulate the phenotype of blood-cell types not yet investigated such as neutrophils, needs to be analyzed.

\section{CONCLUSION}

In this review, we described the current knowledge regarding the quantitative and qualitative profiles of EVs in SCD patients, the clinical conditions modulating these plasma concentrations, the mechanisms involved in their genesis and their biological properties. While high plasma levels of EVs have been reproducibly described, uncertainties remain about their cellular origins. Nevertheless, these vesicles, both sEVs and m/lEVs, are able to modulate key processes of SCD pathophysiology and are therefore bio-effectors in SCD.

\section{AUTHOR CONTRIBUTIONS}

PC and MR conceived the concept and wrote the article. EN and YG edited and significantly improved the manuscript. EN drawn the figures. All authors contributed to the article and approved the submitted version.

\section{FUNDING}

This study was supported by the Laboratoire d'Excellence du Globule Rouge (Labex GR-Ex).

\section{ACKNOWLEDGMENTS}

We would like to deeply thank all the patients who participated in the different studies reported in this manuscript and therefore allowed for a better understanding of EVs role in the pathophysiology of SCD. 
haemoglobin. Nature. (1957) 180:326-8. doi: $10.1038 / 180$ $326 \mathrm{a} 0$

4. Rees DC, Williams TN, Gladwin MT. Sickle-cell disease. Lancet. (2010) 376:2018-31. doi: 10.1016/S0140-6736(10)61029-X

5. Piel FB, Steinberg MH, Rees DC. Sickle cell disease. N Engl J Med. (2017) 376:1561-73. doi: 10.1056/NEJMra1510865

6. Nardo-Marino A, Brousse V, Rees D. Emerging therapies in sickle cell disease. Br J Haematol. (2020) 190:149-72. doi: 10.1111/bjh.16504

7. Lettre $G$. The search for genetic modifiers of disease severity in the $\beta$ hemoglobinopathies. Cold Spring Harb Perspect Med. (2012) 2:a015032. doi: 10.1101/cshperspect.a015032

8. Mohandas N, Chasis JA. Red blood cell deformability, membrane material properties and shape: regulation by transmembrane, skeletal and cytosolic proteins and lipids. Semin Hematol. (1993) 30:171-92.

9. Hierso R, Waltz X, Mora P, Romana M, Lemonne N, Connes P, et al. Effects of oxidative stress on red blood cell rheology in sickle cell patients. $\mathrm{Br} \mathrm{J}$ Haematol. (2014) 166:601-6. doi: 10.1111/bjh.12912

10. Connes P, Lamarre Y, Waltz X, Ballas SK, Lemonne N, Etienne-Julan M, et al. Haemolysis and abnormal haemorheology in sickle cell anaemia. $\mathrm{Br} J$ Haematol. (2014) 165:564-72. doi: 10.1111/bjh.12786

11. Kato GJ, Piel FB, Reid CD, Gaston MH, Ohene-Frempong K, Krishnamurti L, et al. Sickle cell disease. Nat Rev Dis Primers. (2018) 4:18010. doi: $10.1038 /$ nrdp.2018.10

12. Mozzarelli A, Hofrichter J, Eaton WA. Delay time of hemoglobin S polymerization prevents most cells from sickling in vivo. Science. (1987) 237:500-6. doi: 10.1126/science.3603036

13. Kaul DK, Fabry ME, Nagel RL. Microvascular sites and characteristics of sickle cell adhesion to vascular endothelium in shear flow conditions: pathophysiological implications. Proc Natl Acad Sci USA. (1989) 86:3356-60. doi: 10.1073/pnas.86.9.3356

14. Belcher JD, Marker PH, Weber JP, Hebbel RP, Vercellotti GM. Activated monocytes in sickle cell disease: potential role in the activation of vascular endothelium and vaso-occlusion. Blood. (2000) 96:2451-9. doi: 10.1182/blood.V96.7.2451

15. Koehl B, Nivoit P, El Nemer W, Lenoir O, Hermand P, Pereira C, et al. The endothelin $\mathrm{B}$ receptor plays a crucial role in the adhesion of neutrophils to the endothelium in sickle cell disease. Haematologica. (2017) 102:1161-72. doi: 10.3324/haematol.2016.156869

16. Zhang D, Xu C, Manwani D, Frenette PS. Neutrophils, platelets, and inflammatory pathways at the nexus of sickle cell disease pathophysiology. Blood. (2016) 127:801-9. doi: 10.1182/blood-2015-09-618538

17. Wun T, Paglieroni T, Tablin F, Welborn J, Nelson K, Cheung A. Platelet activation and platelet-erythrocyte aggregates in patients with sickle cell anemia. J Lab Clin Med. (1997) 129:507-16. doi: 10.1016/S0022-2143(97)90005-6

18. Brittain HA, Eckman JR, Swerlick RA, Howard RJ, Wick TM. Thrombospondin from activated platelets promotes sickle erythrocyte adherence to human microvascular endothelium under physiologic flow: a potential role for platelet activation in sickle cell vaso-occlusion. Blood. (1993) 81:2137-43. doi: 10.1182/blood.V81.8.2137.2137

19. Zarbock A, Polanowska-Grabowska RK, Ley K. Platelet-neutrophilinteractions: linking hemostasis and inflammation. Blood Rev. (2007) 21:99111. doi: 10.1016/j.blre.2006.06.001

20. Curtis SA, Danda N, Etzion Z, Cohen HW, Billett HH. Elevated steady state WBC and platelet counts are associated with frequent emergency room use in adults with sickle cell anemia. PLoS ONE. (2015) 10:e0133116. doi: 10.1371/journal.pone.0133116

21. Polanowska-Grabowska R, Wallace K, Field JJ, Chen L, Marshall MA, et al. P-selectin-mediated platelet-neutrophil aggregate formation activates neutrophils in mouse and human sickle cell disease. Arterioscler Thromb Vasc Biol. (2010) 30:2392-9. doi: 10.1161/ATVBAHA.110.211615

22. Nebor D, Bowers A, Hardy-Dessources MD, Knight-Madden J, Romana M, Reid $\mathrm{H}$, et al. Frequency of pain crises in sickle cell anemia and its relationship with the sympatho-vagal balance, blood viscosity and inflammation. Haematologica. (2011) 96:1589-94. doi: 10.3324/haematol.2011.047365

23. Lamarre Y, Romana M, Waltz X, Lalanne-Mistrih ML, Tressières B, DivialleDoumdo L, et al. Hemorheological risk factors of acute chest syndrome and painful vaso-occlusive crisis in children with sickle cell disease. Haematologica. (2012) 97:1641-7. doi: 10.3324/haematol.2012.066670

24. Connes P, Alexy T, Detterich J, Romana M, Hardy-Dessources MD, Ballas SK. The role of blood rheology in sickle cell disease. Blood Rev. (2016) 30:111-8. doi: 10.1016/j.blre.2015.08.005

25. Hebbel RP. Beyond hemoglobin polymerization: the red blood cell membrane and sickle disease pathophysiology. Blood. (1991) 77:214-37. doi: 10.1182/blood.V77.2.214.214

26. Nagababu E, Fabry ME, Nagel RL, Rifkind JM. Heme degradation and oxidative stress in murine models for hemoglobinopathies: thalassemia, sickle cell disease and hemoglobin C disease. Blood Cells Mol Dis. (2008) 41:60-6. doi: 10.1016/j.bcmd.2007.12.003

27. Aslan M, Ryan TM, Adler B, Townes TM, Parks DA, Thompson JA, et al. Oxygen radical inhibition of nitric oxide-dependent vascular function in sickle cell disease. Proc Natl Acad Sci USA. (2001) 98:15215-20. doi: 10.1073/pnas.221292098

28. George A, Pushkaran S, Konstantinidis DG, Koochaki S, Malik P, Mohandas N, et al. Erythrocyte NADPH oxidase activity modulated by Rac GTPases, $\mathrm{PKC}$, and plasma cytokines contributes to oxidative stress in sickle cell disease. Blood. (2013) 121:2099-107. doi: 10.1182/blood-2012-07-441188

29. Detterich JA, Liu H, Suriany S, Kato RM, Chalacheva P, Tedla B, et al. Erythrocyte and plasma oxidative stress appears to be compensated in patients with sickle cell disease during a period of relative health, despite the presence of known oxidative agents. Free Radic Biol Med. (2019) 141:408-15. doi: 10.1016/j.freeradbiomed.2019.07.004

30. Yalamanoglu A, Deuel JW, Hunt RC, Baek JH, Hassell K, Redinius K, et al. Depletion of haptoglobin and hemopexin promote hemoglobin-mediated lipoprotein oxidation in sickle cell disease. Am J Physiol Lung Cell Mol Physiol. (2018) 315:L765-74. doi: 10.1152/ajplung.00269.2018

31. Ofori-Acquah SF, Hazra R, Orikogbo OO, Crosby D, Flage B, Ackah EB, et al. Hemopexin deficiency promotes acute kidney injury in sickle cell disease. Blood. (2020) 135:1044-8. doi: 10.1182/blood.2019002653

32. Morris CR, Suh JH, Hagar W, Larkin S, Bland DA, Steinberg MH, et al. Erythrocyte glutamine depletion, altered redox environment, and pulmonary hypertension in sickle cell disease. Blood. (2008) 111:402-10. doi: 10.1182/blood-2007-04-081703

33. Rank BH, Carlsson J, Hebbel RP. Abnormal redox status of membraneprotein thiols in sickle erythrocytes. J Clin Invest. (1985) 75:1531-7. doi: 10.1172/JCI111857

34. Nader E, Conran N, Romana M, Connes P. Vasculopathy in sickle cell disease: from red blood cell sickling to vascular dysfunction. Compr Physiol. (2021) 11:1785-803. doi: 10.1002/cphy.c200024

35. Lavrovsky Y, Chatterjee B, Clark RA, Roy AK. Role of redox-regulated transcription factors in inflammation, aging and age-related diseases. Exp Gerontol. (2000) 35:521-32. doi: 10.1016/S0531-5565(00)00118-2

36. Dutra FF, Alves LS, Rodrigues D, Fernandez PL, de Oliveira RB, Golenbock DT, et al. Hemolysis-induced lethality involves inflammasome activation by heme. Proc Natl Acad Sci USA. (2014) 111:E4110-8. doi: $10.1073 /$ pnas. 1405023111

37. Vinchi F, Costa da Silva M, Ingoglia G, Petrillo S, Brinkman N, Zuercher $A$, et al. Hemopexin therapy reverts heme-induced proinflammatory phenotypic switching of macrophages in a mouse model of sickle cell disease. Blood. (2016) 127:473-86. doi: 10.1182/blood-2015-08-663245

38. Chen G, Zhang D, Fuchs TA, Manwani D, Wagner DD, Frenette PS. Heme-induced neutrophil extracellular traps contribute to the pathogenesis of sickle cell disease. Blood. (2014) 123:3818-27. doi: 10.1182/blood-2013-10-529982

39. Bourne JH, Colicchia M, Di Y, Martin E, Slater A, Roumenina LT, et al. Heme induces human and mouse platelet activation through C-type-lectin-like receptor-2. Haematologica. (2021) 106:626-9. doi: 10.3324/haematol.2020.246488

40. Belcher JD, Chen C, Nguyen J, Milbauer L, Abdulla F, Alayash AI, et al. Heme triggers TLR4 signaling leading to endothelial cell activation and vaso-occlusion in murine sickle cell disease. Blood. (2014) 123:377-90. doi: 10.1182/blood-2013-04-495887

41. Folco EJ, Mawson TL, Vromman A, Bernardes-Souza B, Franck G, Persson $\mathrm{O}$, et al. Neutrophil extracellular traps induce endothelial cell activation and tissue factor production through interleukin-1 $\alpha$ and cathepsin G. Arterioscler 
Thromb Vasc Biol. (2018) 38:1901-12. doi: 10.1161/ATVBAHA.118. 311150

42. Hebbel RP, Morgan WT, Eaton JW, Hedlund BE. Accelerated autoxidation and heme loss due to instability of sickle hemoglobin. Proc Natl Acad Sci USA. (1988) 85:237-41. doi: 10.1073/pnas.85.1.237

43. Möckesch B, Connes P, Charlot K, Skinner S, Hardy-Dessources MD, Romana $\mathrm{M}$, et al. Association between oxidative stress and vascular reactivity in children with sickle cell anaemia and sickle haemoglobin $\mathrm{C}$ disease. $\mathrm{Br} \mathrm{J}$ Haematol. (2017) 178:468-75. doi: 10.1111/bjh.14693

44. Renoux C, Joly P, Faes C, Mury P, Eglenen B, Turkay M, et al. Association between oxidative stress, genetic factors, and clinical severity in children with sickle cell anemia. J Pediatr. (2018) 195:228-35. doi: 10.1016/j.jpeds.2017.12.021

45. Gbotosho OT, Kapetanaki MG, Kato GJ. The worst things in life are free: the role of free heme in sickle cell disease. Front Immunol. (2021) 11:561917. doi: 10.3389/fimmu.2020.561917

46. Figueiredo RT, Fernandez PL, Mourao-Sa DS, Porto BN, Dutra FF, Alves LS, et al. Characterization of heme as activator of Toll-like receptor 4. J Biol Chem. (2007) 282:20221-9. doi: 10.1074/jbc.M610737200

47. Ghosh S, Adisa OA, Chappa P, Tan F, Jackson KA, Archer DR, et al. Extracellular hemin crisis triggers acute chest syndrome in sickle mice. J Clin Invest. (2013) 123:4809-20. doi: 10.1172/JCI64578

48. Thålin C, Hisada Y, Lundström S, Mackman N, Wallén H. Neutrophil extracellular traps: villains and targets in arterial, venous, and cancerassociated thrombosis. Arterioscler Thromb Vasc Biol. (2019) 39:1724-38. doi: 10.1161/ATVBAHA.119.312463

49. De Caterina R, Libby P, Peng HB, Thannickal VJ, Rajavashisth TB, Gimbrone MA Jr, et al. Nitric oxide decreases cytokine-induced endothelial activation. Nitric oxide selectively reduces endothelial expression of adhesion molecules and proinflammatory cytokines. J Clin Invest. (1995) 96:60-8. doi: 10.1172/JCI118074

50. Radomski MW, Moncada S. The biological and pharmacological role of nitric oxide in platelet function. Adv Exp Med Biol. (1993) 344:251-64. doi: 10.1007/978-1-4615-2994-1_20

51. Reiter CD, Wang X, Tanus-Santos JE, Hogg N, Cannon RO 3rd, Schechter AN, et al. Cell-free hemoglobin limits nitric oxide bioavailability in sicklecell disease. Nat Med. (2002) 8:1383-9. doi: 10.1038/nm1202-799

52. Rother RP, Bell L, Hillmen P, Gladwin MT. The clinical sequelae of intravascular hemolysis and extracellular plasma hemoglobin: a novel mechanism of human disease. JAMA. (2005) 293:1653-62. doi: 10.1001/jama.293.13.1653

53. Morris CR, Kato GJ, Poljakovic M, Wang X, Blackwelder WC, Sachdev V, et al. Dysregulated arginine metabolism, hemolysis-associated pulmonary hypertension, and mortality in sickle cell disease. JAMA. (2005) 294:81-90. doi: 10.1001/jama.294.1.81

54. Gladwin MT, Sachdev V, Jison ML, Shizukuda Y, Plehn JF, Minter K et al. Pulmonary hypertension as a risk factor for death in patients with sickle cell disease. N Engl J Med. (2004) 350:886-95. doi: 10.1056/NEJMoa035477

55. Kato GJ, McGowan V, Machado RF, Little JA, Taylor J 6th, Morris CR, et al. Lactate dehydrogenase as a biomarker of hemolysis-associated nitric oxide resistance, priapism, leg ulceration, pulmonary hypertension, and death in patients with sickle cell disease. Blood. (2006) 107:2279-85. doi: 10.1182/blood-2005-06-2373

56. Baldwin C, Nolan VG, Wyszynski DF, Ma QL, Sebastiani P, Embury SH, et al. Association of klotho, bone morphogenic protein 6, and annexin A2 polymorphisms with sickle cell osteonecrosis. Blood. (2005) 106:372-5. doi: 10.1182/blood-2005-02-0548

57. Bernaudin F, Verlhac S, Chevret S, Torres M, Coic L, Arnaud C, et al. G6PD deficiency, absence of alpha-thalassemia, and hemolytic rate at baseline are significant independent risk factors for abnormally high cerebral velocities in patients with sickle cell anemia. Blood. (2008) 112:4314-7. doi: 10.1182/blood-2008-03-143891

58. Day TG, Drasar ER, Fulford T, Sharpe CC, Thein SL. Association between hemolysis and albuminuria in adults with sickle cell anemia. Haematologica. (2012) 97:201-5. doi: 10.3324/haematol.2011.050336

59. Ataga KI, Key NS. Hypercoagulability in sickle cell disease: new approaches to an old problem. Hematol Am Soc Hematol Educ Progr. (2007) 1:91-6. doi: 10.1182/asheducation-2007.1.91
60. De Franceschi L, Cappellini MD, Olivieri O. Thrombosis and sickle cell disease. Semin Thromb Hemost. (2011) 37:226-36. doi: 10.1055/s-0031-1273087

61. Noubouossie D, Key NS, Ataga KI. Coagulation abnormalities of sickle cell disease: relationship with clinical outcomes and the effect of disease modifying therapies. Blood Rev. (2016) 30:245-56. doi: 10.1016/j.blre.2015.12.003

62. Setty BN, Key NS, Rao AK, Gayen-Betal S, Krishnan S, Dampier CD, et al. Tissue factor-positive monocytes in children with sickle cell disease: correlation with biomarkers of haemolysis. Br J Haematol. (2012) 157:37080. doi: 10.1111/j.1365-2141.2012.09065.x

63. Key NS, Slungaard A, Dandelet L, Nelson SC, Moertel C, Styles LA, et al. Whole blood tissue factor procoagulant activity is elevated in patients with sickle cell disease. Blood. (1998) 91:4216-23. doi: 10.1182/blood.V91.11.4216

64. Solovey A, Gui L, Key NS, Hebbel RP. Tissue factor expression by endothelial cells in sickle cell anemia. J Clin Invest. (1998) 101:1899-904. doi: 10.1172/JCI1932

65. Setty BN, Betal SG, Zhang J, Stuart MJ. Heme induces endothelial tissue factor expression: potential role in hemostatic activation in patients with hemolytic anemia. J Thromb Haemost. (2008) 6:2202-9. doi: 10.1111/j.1538-7836.2008.03177.x

66. Gordon EM, Klein BL, Berman BW, Strandjord SE, Simon JE, Coccia PF. Reduction of contact factors in sickle cell disease. J Pediatr. (1985) 106:42730. doi: 10.1016/S0022-3476(85)80669-7

67. Setty BN, Rao AK, Stuart MJ. Thrombophilia in sickle cell disease: the red cell connection. Blood. (2001) 98:3228-33. doi: 10.1182/blood.V98.12.3228

68. Setty BN, Kulkarni S, Rao AK, Stuart MJ. Fetal hemoglobin in sickle cell disease: relationship to erythrocyte phosphatidylserine exposure and coagulation activation. Blood. (2000) 96:1119-24. doi: 10.1182/blood.V96.3.1119

69. Tumburu L, Ghosh-Choudhary S, Seifuddin F, Barbu EA, Yang $S$, Ahmad MM, et al. Circulating mitochondrial DNA is a proinflammatory DAMP in sickle cell disease. Blood. (2021) 137:3116-3126. doi: $10.1182 /$ blood.2020009063

70. Vasavda N, Ulug P, Kondaveeti S, Ramasamy K, Sugai T, Cheung G, et al. Circulating DNA: a potential marker of sickle cell crisis. $\mathrm{Br} J$ Haematol. (2007) 139:331-6. doi: 10.1111/j.1365-2141.2007.06775.x

71. Schimmel M, Nur E, Biemond BJ, van Mierlo GJ, Solati S, Brandjes DP, et al. Nucleosomes and neutrophil activation in sickle cell disease painful crisis. Haematologica. (2013) 98:1797-803. doi: 10.3324/haematol.2013.088021

72. Naik RP, Streiff MB, Haywood C Jr, Nelson JA, Lanzkron S. Venous thromboembolism in adults with sickle cell disease: a serious and under- recognized complication. Am J Med. (2013) 126:443-9. doi: 10.1016/j.amjmed.2012.12.016

73. Naik RP, Streiff MB, Haywood C Jr, Segal JB, Lanzkron S. Venous thromboembolism incidence in the cooperative study of sickle cell disease. J Thromb Haemost. (2014) 12:2010-6. doi: 10.1111/jth.12744

74. Ataga KI, Moore CG, Hillery CA, Jones S, Whinna HC, Strayhorn D, et al. Coagulation activation and inflammation in sickle cell diseaseassociated pulmonary hypertension. Haematologica. (2008) 93:20-6. doi: 10.3324/haematol.11763

75. Shet AS, Lizarralde-Iragorri MA, Naik RP. The molecular basis for the prothrombotic state in sickle cell disease. Haematologica. (2020) 105:236879. doi: 10.3324/haematol.2019.239350

76. Yáñez-Mó $\mathrm{M}$, Siljander $\mathrm{PR}$, Andreu $\mathrm{Z}$, Zavec $\mathrm{AB}$, Borràs $\mathrm{FE}$, Buzas EI, et al. Biological properties of extracellular vesicles and their physiological functions. J Extracell Vesicles. (2015) 4:27066. doi: 10.3402/jev.v4.27066

77. Colombo M, Raposo G, Théry C. Biogenesis, secretion, and intercellular interactions of exosomes and other extracellular vesicles. Annu Rev Cell Dev Biol. (2014) 30:255-89. doi: 10.1146/annurev-cellbio-101512-122326

78. Morel O, Jesel L, Freyssinet JM, Toti F. Cellular mechanisms underlying the formation of circulating microparticles. Arterioscler Thromb Vasc Biol. (2011) 31:15-26. doi: 10.1161/ATVBAHA.109.200956

79. Willms E, Johansson HJ, Mäger I, Lee Y, Blomberg KE, Sadik M, et al. Cells release subpopulations of exosomes with distinct molecular and biological properties. Sci Rep. (2016) 6:22519. doi: 10.1038/srep22519

80. Atkin-Smith GK, Tixeira R, Paone S, Mathivanan S, Collins C, Liem M, et al. A novel mechanism of generating extracellular vesicles during apoptosis 
via a beads-on-a-string membrane structure. Nat Commun. (2015) 6:7439. doi: $10.1038 /$ ncomms 8439

81. Erdbrügger U, Lannigan J. Analytical challenges of extracellular vesicle detection: a comparison of different techniques. Cytometry A. (2016) 89:12334. doi: 10.1002/cyto.a.22795

82. Szatanek R, Baj-Krzyworzeka M, Zimoch J, Lekka M, Siedlar M, Baran J. The methods of choice for extracellular vesicles (EVs) characterization. Int J Mol Sci. (2017) 18:1153. doi: 10.3390/ijms18061153

83. Jayachandran M, Miller VM, Heit JA, Owen WG. Methodology for isolation, identification and characterization of microvesicles in peripheral blood. $J$ Immunol Methods. (2012) 375:207-14. doi: 10.1016/j.jim.2011.10.012

84. Lacroix R, Judicone C, Poncelet P, Robert S, Arnaud L, Sampol J, et al. Impact of pre-analytical parameters on the measurement of circulating microparticles: towards standardization of protocol. J Thromb Haemost. (2012) 10:437-46. doi: 10.1111/j.1538-7836.2011.04610.x

85. Mullier F, Bailly N, Chatelain C, Chatelain B, Dogné JM. Pre-analytical issues in the measurement of circulating microparticles: current recommendations and pending questions. J Thromb Haemost. (2013) 11:693-6. doi: 10.1111/jth.12171

86. Lacroix R, Judicone C, Mooberry M, Boucekine M, Key NS, Dignat-George $\mathrm{F}$, et al. Standardization of pre-analytical variables in plasma microparticle determination: results of the International Society on Thrombosis and Haemostasis SSC Collaborative workshop. J Thromb Haemost. (2013). doi: 10.1111/jth.12207. [Epub ahead of print].

87. Cointe S, Judicone C, Robert S, Mooberry MJ, Poncelet P, Wauben M, et al. Standardization of microparticle enumeration across different flow cytometry platforms: results of a multicenter collaborative workshop. $J$ Thromb Haemost. (2017) 15:187-93. doi: 10.1111/jth.13514

88. Wolf $\mathrm{P}$. The nature and significance of platelet products in human plasma. Br J Haematol. (1967) 13:269-88. doi: 10.1111/j.1365-2141.1967.tb08741.x

89. Raposo G, Nijman HW, Stoorvogel W, Liejendekker R, Harding CV, Melief CJ, et al. B lymphocytes secrete antigen-presenting vesicles. J Exp Med. (1996) 183:1161-72. doi: 10.1084/jem.183.3.1161

90. Skog J, Würdinger T, van Rijn S, Meijer DH, Gainche L, Sena-Esteves M, et al. Glioblastoma microvesicles transport RNA and proteins that promote tumour growth and provide diagnostic biomarkers. Nat Cell Biol. (2008) 10:1470-6. doi: 10.1038/ncb1800

91. Wolfers J, Lozier A, Raposo G, Regnault A, Théry C, Masurier C, et al. Tumor-derived exosomes are a source of shared tumor rejection antigens for CTL cross-priming. Nat Med. (2001) 7:297-303. doi: 10.1038/85438

92. Valadi H, Ekström K, Bossios A, Sjöstrand M, Lee JJ, Lötvall JO. Exosome- mediated transfer of mRNAs and microRNAs is a novel mechanism of genetic exchange between cells. Nat Cell Biol. (2007) 9:654-9. doi: $10.1038 /$ ncb1596

93. Ridger VC, Boulanger CM, Angelillo-Scherrer A, Badimon L, Blanc-Brude $\mathrm{O}$, Bochaton-Piallat ML, et al. Microvesicles in vascular homeostasis and diseases. Position Paper of the European Society of Cardiology (ESC) Working Group on Atherosclerosis and Vascular Biology. Thromb Haemost. (2017) 117:1296-316. doi: 10.1160/TH16-12-0943

94. Jansen F, Nickenig G, Werner N. Extracellular vesicles in cardiovascular disease: potential applications in diagnosis, prognosis, and epidemiology. Circ Res. (2017) 120:1649-57. doi: 10.1161/CIRCRESAHA.117.310752

95. Feng B, Chen Y, Luo Y, Chen M, Li X, Ni Y. Circulating level of microparticles and their correlation with arterial elasticity and endothelium-dependent dilation in patients with type 2 diabetes mellitus. Atherosclerosis. (2010) 208:264-9. doi: 10.1016/j.atherosclerosis.2009.06.037

96. Witwer KW, Soekmadji C, Hill AF, Wauben MH, Buzás EI, Di Vizio D, et al. Updating the MISEV minimal requirements for extracellular vesicle studies: building bridges to reproducibility. J Extracell Vesicles. (2017) 6:1396823. doi: 10.1080/20013078.2017.1396823

97. Shet AS, Aras O, Gupta K, Hass MJ, Rausch DJ, Saba N, et al. Sickle blood contains tissue factor-positive microparticles derived from endothelial cells and monocytes. Blood. (2003) 102:2678-83. doi: 10.1182/blood-2003-03-0693

98. Tantawy AA, Adly AA, Ismail EA, Habeeb NM, Farouk A. Circulating platelet and erythrocyte microparticles in young children and adolescents with sickle cell disease: relation to cardiovascular complications. Platelets. (2013) 24:605-14. doi: 10.3109/09537104.2012.749397
99. Gerotziafas GT, Van Dreden P, Chaari M, Galea V, Khaterchi A, Lionnet $\mathrm{F}$, et al. The acceleration of the propagation phase of thrombin generation in patients with steady-state sickle cell disease is associated with circulating erythrocyte-derived microparticles. Thromb Haemost. (2012) 107:1044-52. doi: 10.1160/TH11-10-0689

100. Kasar M, Boga C, Yeral M, Asma S, Kozanoglu I, Ozdogu H. Clinical significance of circulating blood and endothelial cell microparticles in sickle- cell disease. J Thromb Thrombolysis. (2014) 38:167-75. doi: 10.1007/s11239-013-1028-3

101. van Tits LJ, van Heerde WL, Landburg PP, Boderie MJ, Muskiet FA, Jacobs $\mathrm{N}$, et al. Plasma annexin A5 and microparticle phosphatidylserine levels are elevated in sickle cell disease and increase further during painful crisis. Biochem Biophys Res Commun. (2009) 390:161-4. doi: 10.1016/j.bbrc.2009.09.102

102. Dembélé AK, Lapoumeroulie C, Diaw M, Tessougue O, Offredo L, Diallo $\mathrm{DA}$, et al. Cell-derived microparticles and sickle cell disease chronic vasculopathy in sub-Saharan Africa: a multinational study. $\mathrm{Br} J$ Haematol. (2021) 192:634-42. doi: 10.1111/bjh.17242

103. Garnier Y, Ferdinand S, Etienne-Julan M, Elana G, Petras M, Doumdo $\mathrm{L}$, et al. Differences of microparticle patterns between sickle cell anemia and hemoglobin SC patients. PLoS ONE. (2017) 12:e0177397. doi: 10.1371/journal.pone.0177397

104. Nebor D, Bowers A, Connes P, Hardy-Dessources MD, Knight-Madden J, Cumming V, et al. Plasma concentration of platelet-derived microparticles is related to painful vaso-occlusive phenotype severity in sickle cell anemia. PLoS ONE. (2014) 9:e87243. doi: 10.1371/journal.pone.0087243

105. Olatunya OS, Lanaro C, Longhini AL, Penteado CFF, Fertrin KY, Adekile A, et al. Red blood cells microparticles are associated with hemolysis markers and may contribute to clinical events among sickle cell disease patients. Ann Hematol. (2019) 98:2507-21. doi: 10.1007/s00277-019-03792-x

106. Khalyfa A, Khalyfa AA, Akbarpour M, Connes P, Romana M, LappingCarr G, et al. Extracellular microvesicle microRNAs in children with sickle cell anaemia with divergent clinical phenotypes. Br J Haematol. (2016) 174:786-98. doi: 10.1111/bjh.14104

107. Lapping-Carr G, Khalyfa A, Rangel S, Darlington W, Beyer EC, Peddinti $\mathrm{R}$, et al. Exosomes contribute to endothelial integrity and acute chest syndrome risk: preliminary findings. Pediatr Pulmonol. (2017) 52:1478-85. doi: $10.1002 /$ ppul.23698

108. Marsh A, Schiffelers R, Kuypers F, Larkin S, Gildengorin G, van Solinge W, et al. Microparticles as biomarkers of osteonecrosis of the hip in sickle cell disease. Br J Haematol. (2015) 168:135-8. doi: 10.1111/bjh.13110

109. Piccin A, Murphy C, Eakins E, Kunde J, Corvetta D, Di Pierro A, et al. Circulating microparticles, protein $\mathrm{C}$, free protein $\mathrm{S}$ and endothelial vascular markers in children with sickle cell anaemia. J Extracell Vesicles. (2015) 4:28414. doi: 10.3402/jev.v4.28414

110. Hebbel RP, Key NS. Microparticles in sickle cell anaemia: promise and pitfalls. Br J Haematol. (2016) 174:16-29. doi: 10.1111/bjh.14112

111. Romana M, Connes P, Key NS. Microparticles in sickle cell disease. Clin Hemorheol Microcirc. (2018) 68:319-29. doi: 10.3233/CH-189014

112. Hierso R, Lemonne N, Villaescusa R, Lalanne-Mistrih ML, Charlot K, Etienne- Julan $\mathrm{M}$, et al. Exacerbation of oxidative stress during sickle vasoocclusive crisis is associated with decreased anti-band 3 autoantibodies rate and increased red blood cell-derived microparticle level: a prospective study. Br J Haematol. (2017) 176:805-13. doi: 10.1111/bjh.14476

113. Nébor D, Romana M, Santiago R, Vachiery N, Picot J, Broquere C, et al. Fetal hemoglobin andhydroxycarbamide moduate both plasma concentration and cellular origin ofcirculating microparticles in sickle cell anemia children. Haematologica. (2013) 98:862-7. doi: 10.3324/haematol.2012.073619

114. Westerman M, Pizzey A, Hirschman J, Cerino M, Weil-Weiner Y, Ramotar P, et al. Microvesicles in haemoglobinopathies offer insights into mechanisms of hypercoagulability, haemolysis and the effects of therapy. Br J Haematol. (2008) 142:126-35. doi: 10.1111/j.1365-2141.2008.07155.x

115. Brunetta DM, De Santis GC, Silva-Pinto AC, Oliveira de Oliveira LC, Covas DT. Hydroxyurea increases plasma concentrations of microparticles and reduces coagulation activation and fibrinolysis in patients with sickle cell anemia. Acta Haematol. (2015) 133:287-94. doi: 10.1159/000362148

116. Garnier Y, Ferdinand S, Connes P, Garnier M, Etienne-Julan M, Lemonne N, et al. Decrease of externalized phosphatidylserine density on red blood cell- 
derived microparticles in SCA patients treated with hydroxycarbamide. $\mathrm{Br} \mathrm{J}$ Haematol. (2018) 182:448-51. doi: 10.1111/bjh.14810

117. Allan D, Limbrick AR, Thomas P, Westerman MP. Release of spectrin-free spicules on reoxygenation of sickled erythrocytes. Nature. (1982) 295:612-3. doi: 10.1038/295612a0

118. Franck PF, Bevers EM, Lubin BH, Comfurius P, Chiu DT, Op den Kamp JA, et al. Uncoupling of the membrane skeleton from the lipid bilayer. The cause of accelerated phospholipid flip-flop leading to an enhanced procoagulant activity of sickled cells. J Clin Invest. (1985) 75:183-90. doi: $10.1172 /$ JCI111672

119. Liu SC, Derick LH, Zhai S, Palek J. Uncoupling of the spectrin-based skeleton from the lipid bilayer in sickled red cells. Science. (1991) 252:574-6. doi: $10.1126 /$ science.2020854

120. Rank BH, Moyer NL, Hebbel RP. Vesiculation of sickle erythrocytes during thermal stress. Blood. (1988) 72:1060-3. doi: 10.1182/blood.V72.3.1060.bloodjournal7231060

121. Merciris P, Hardy-Dessources MD, Giraud F. Deoxygenation of sickle cells stimulates Syk tyrosine kinase and inhibits a membrane tyrosine phosphatase. Blood. (2001) 98:3121-7. doi: 10.1182/blood.V98.10.3121

122. Brunati AM, Bordin L, Clari G, James P, Quadroni M, Baritono E, et al. Sequential phosphorylation of protein band 3 by Syk and Lyn tyrosine kinases in intact human erythrocytes: identification of primary and secondary phosphorylation sites. Blood. (2000) 96:1550-7. doi: 10.1182/blood.V96.4.1550

123. Noomuna P, Risinger M, Zhou S, Seu K, Man Y, An R, et al. Inhibition of Band 3 tyrosine phosphorylation: a new mechanism for treatment of sickle cell disease. Br J Haematol. (2020) 190:599-609. doi: 10.1111/bjh.16671

124. Azouzi S, Romana M, Arashiki N, Takakuwa Y, El Nemer W, Peyrard T, et al. Band 3 phosphorylation induces irreversible alterations of stored red blood cells. Am J Hematol. (2018) 93:E110-2. doi: 10.1002/ajh.25044

125. Nader E, Romana M, Guillot N, Fort R, Stauffer E, Lemonne N, et al. Association between nitric oxide, oxidative stress, eryptosis, red blood cell microparticles, and vascular function in sickle cell anemia. Front Immunol. (2020) 11:551441. doi: 10.3389/fimmu.2020.551441

126. van Beers EJ, Schaap MC, Berckmans RJ, Nieuwland R, Sturk A, van Doormaal FF, et al. Circulating erythrocyte-derived microparticles are associated with coagulation activation in sickle cell disease. Haematologica. (2009) 94:1513-9. doi: 10.3324/haematol.2009.008938

127. Nouraie M, Lee JS, Zhang Y, Kanias T, Zhao X, Xiong Z, et al. The relationship between the severity of hemolysis, clinical manifestations and risk of death in 415 patients with sickle cell anemia in the US and Europe. Haematologica. (2013) 98:464-72. doi: 10.3324/haematol.2012. 068965

128. López DJ, Egido-Gabas M, López-Montero I, Busto JV, Casas J, Garnier $\mathrm{M}$, et al. Accumulated bending energy elicits neutral sphingomyelinase activity in human red blood cells. Biophys J. (2012) 102:2077-85. doi: 10.1016/j.bpj.2012.03.020

129. Awojoodu AO, Keegan PM, Lane AR, Zhang Y, Lynch KR, Platt MO, et al. Acid sphingomyelinase is activated in sickle cell erythrocytes and contributes to inflammatory microparticle generation in SCD. Blood. (2014) 124:1941-50. doi: 10.1182/blood-2014-01-543652

130. Camus SM, Gausserès B, Bonnin P, Loufrani L, Grimaud L, Charue D, et al. Erythrocyte microparticles can induce kidney vaso-occlusions in a murine model of sickle cell disease. Blood. (2012) 120:5050-8. doi: 10.1182/blood-2012-02-413138

131. Annarapu GK, Singhal R, Gupta A, Chawla S, Batra H, Seth T, et al. HbS binding to GP1b $\alpha$ activates platelets in sickle cell disease. PLoS ONE. (2016) 11:e0167899. doi: 10.1371/journal.pone.0167899

132. Willekens FL, Werre JM, Groenen-Döpp YA, RoerdinkholderStoelwinder B, de Pauw B, Bosman GJ. Erythrocyte vesiculation: a self-protective mechanism? $\mathrm{Br} J$ Haematol. (2008) 141:549-56. doi: 10.1111/j.1365-2141.2008.07055.x
133. van Der Meijden PE, Van Schilfgaarde M, Van Oerle R, Renné T, ten Cate $\mathrm{H}$, Spronk HM. Platelet- and erythrocyte-derived microparticles trigger thrombin generation via factor XIIa. J Thromb Haemost. (2012) 10:1355-62. doi: 10.1111/j.1538-7836.2012.04758.x

134. Koshiar RL, Somajo S, Norström E, Dahlbäck B. Erythrocytederived microparticles supporting activated protein C-mediated regulation of blood coagulation. PLoS ONE. (2014) 9:e104200. doi: 10.1371 /journal.pone. 0104200

135. Noubouossie DF, Henderson MW, Mooberry M, Ilich A, Ellsworth P, Piegore $\mathrm{M}$, et al. Red blood cell microvesicles activate the contact system, leading to factor IX activation via 2 independent pathways. Blood. (2020) 135:755-65. doi: 10.1182/blood.2019001643

136. Camus SM, De Moraes JA, Bonnin P, Abbyad P, Le Jeune S, Lionnet F, et al. Circulating cell membrane microparticles transfer heme to endothelial cells and trigger vasoocclusions in sickle cell disease. Blood. (2015) 125:3805-14. doi: 10.1182/blood-2014-07-589283

137. Merle NS, Grunenwald A, Rajaratnam H, Gnemmi V, Frimat M, Figueres ML, et al. Intravascular hemolysis activates complement via cellfree heme and heme-loaded microvesicles. JCI Insight. (2018) 3:e96910. doi: $10.1172 /$ jci.insight. 96910

138. Prudent M, Crettaz D, Delobel J, Seghatchian J, Tissot JD, Lion N. Differences between calcium-stimulated and storage-induced erythrocyte-derived microvesicles. Transfus Apher Sci. (2015) 53:153-8. doi: 10.1016/j.transci.2015.10.012

139. Jimenez JJ, Jy W, Mauro LM, Soderland C, Horstman LL, Ahn YS. Endothelial cells release phenotypically and quantitatively distinct microparticles in activation and apoptosis. Thromb Res. (2003) 109:175-80. doi: 10.1016/S0049-3848(03)00064-1

140. Garnier Y, Ferdinand S, Garnier M, Cita KC, Hierso R, Claes A, et al. Plasma microparticles of sickle patients during crisis or taking hydroxyurea modify endothelium inflammatory properties. Blood. (2020) 136:247-56. doi: 10.1182/blood.2020004853

141. Donadee C, Raat NJ, Kanias T, Tejero J, Lee JS, Kelley EE, et al. Nitric oxide scavenging by red blood cell microparticles and cell-free hemoglobin as a mechanism for the red cell storage lesion. Circulation. (2011) 124:465-76. doi: 10.1161/CIRCULATIONAHA.110.008698

142. Vats R, Brzoska T, Bennewitz MF, Jimenez MA, Pradhan-Sundd T, Tutuncuoglu E, et al. Platelet extracellular vesicles drive inflammasome-IL$1 \beta$-dependent lung injury in sickle cell disease. Am J Respir Crit Care Med. (2020) 201:33-46. doi: 10.1164/rccm.201807-13700C

143. Fitzgerald W, Freeman ML, Lederman MM, Vasilieva E, Romero R, Margolis L. A system of cytokines encapsulated in extra cellular vesicles. Sci Rep. (2018) 8:8973. doi: 10.1038/s41598-018-27190-x

Conflict of Interest: The authors declare that the research was conducted in the absence of any commercial or financial relationships that could be construed as a potential conflict of interest.

Publisher's Note: All claims expressed in this article are solely those of the authors and do not necessarily represent those of their affiliated organizations, or those of the publisher, the editors and the reviewers. Any product that may be evaluated in this article, or claim that may be made by its manufacturer, is not guaranteed or endorsed by the publisher.

Copyright $\odot 2021$ Nader, Garnier, Connes and Romana. This is an open-access article distributed under the terms of the Creative Commons Attribution License (CC $B Y)$. The use, distribution or reproduction in other forums is permitted, provided the original author(s) and the copyright owner(s) are credited and that the original publication in this journal is cited, in accordance with accepted academic practice. No use, distribution or reproduction is permitted which does not comply with these terms. 